\title{
豪雨時における高齢者施設間の自動車を用いた要配慮者避難の事例分析 \\ EMPIRICAL ANALYSIS OF VEHICLE EVACUATION OF VULNERABLE PEOPLE BETWEEN ELDERLY FACILITIES DURING HEAVY RAINFALL
}

\author{
廖 解放*1, 北後明彦*2, 大津 暢 人*3, \\ 大西一嘉*4, 大村太秀*5
Jiefang LIAO, Akihiko HOKUGO, Nobuhito OHTSU, Kazuyoshi OHNISHI and Taishu OMURA

\begin{abstract}
This study aims to collect useful knowledge about vehicle evacuation such as evacuation time distribution and evacuation traveling velocity. The empirical surveys were conducted on three evacuation cases in Mabi, Okayama during the 2018 Japan Floods. The authors analyzed the data from each evacuation travel of each elderly facility and classified evacuation types based on the time relationship between the evacuation preparation and the evacuation travel. The study provides abundant information including the time used for getting in and off per resident under three ways of transportation in evacuation and calculated the traveling velocity of evacuation vehicles.
\end{abstract}

Keywords : Heavy Rainfall, Elderly Facilities, Vehicle Evacuation of Vulnerable People, Evacuation Time Distribution, Traveling Velocity 豪雨, 高齢者施設, 自動車による要配慮者避難, 所要時間分布, 走行速度

\section{1. はじめに}

近年、日本各地で大規模な災害が発生している。それに伴い様々 な防災計画の見直しが進められている。その中で、要配慮者注1)利用 施設では、2017 年 6 月に水害や土砂災害の危険性がある施設を対 象として避難破保計画の作成が義務化された ${ }^{1)}$ 。しかし、前述の避 難確保計画の作成は各施設に一任されており、被災経験のない施設 管理者や避難訓練を行っていない施設で適切な避難確保計画を作成 することは容易ではない。特に、避難所要時間について計画作成の 手引きでは簡潔に記載されており、施設にとって具体的で実践可能 な計画が練られているかどうかは分からない。

そうした中、2018 年西日本豪雨災害が発生し、西日本で約 28,000 棟の建物が浸水し、237 名が犠牲になった ${ }^{2)}$ 。幸いにも高齢者施設 での人的被害はなかったが、雨漏りや床上浸水等の施設被害数は 276 施設 ${ }^{3)}$ であり、改めて避難の重要性が認識されることになった。

要配慮者の避難所要時間や避難移動を扱う先行研究として、大津 らは、市街地の津波避難訓練において支援者が搬送機材を用いて要 配慮者を避難移動する際の避難移動時間の経過及び搬送機材の避難 輸送力を把握した ${ }^{4)}$ 。しかし、搬送機材として自動車は取り扱って いない。久米らは、原子力災害時における高齢者施設の自動車によ る要配慮者避難に関する研究で、避難時に高齢者を乗車させるため に必要な時間を幾つかの器具を用いて実験により検証している ${ }^{5)}$ 。 しかし、実災害においては、乗車等の時間が実験時と異なる可能性
がある。一方、金井らは、要配慮者利用施設独自の避難開始基準を 検討するために、実災害において、施設の初期対応を時系列に整理 し、避難準備時間と避難移動時間の関係を分析した ${ }^{6)}$ 。その中でも 避難移動時間を試算したが、用いられた乗車時間、降車時間等は座 席での移動状態を仮定したものであり、車椅子のままやストレッチ ヤーのままでの移動状態を考慮していない。

夜間かつ豪雨時に、危険な区域に立地する施設では利用者全員を 自動車で避難させる必要がある場合、避難所要時間をどのように見 積るかについての具体的なデータは少ない。本研究はその一助を担 うものとして、2018 年西日本豪雨における高齢者施設間の自動車に よる要配慮者避難に重点を置き、実災害における避難準備と避難移 動を時系列で整理し、利用者 1 名ごとの乗車時間と降車時間、搬送 車両の走行速度等の解明を目的に研究を行った。

研究方法として、2018 年西日本豪雨に際して、夜間に行われた 3 つの高齢者施設間の自動車による要配慮者避難の全容をヒアリング 調査から明らかにし、避難に関する時系列の作成と利用者の避難移 動の推定を行う。また、避難準備と避難移動の時間関係から避難夕 イプの分類を行った。そして、避難移動時間の分布から各移動状態 下の利用者 1 名ごとの乗車時間と降車時間を抽出し、搬送車両の搬 送 (回送) 時間に基づき走行速度を算出することで、自動車による要 配慮者避難に関する知見を見出す。

なお、本研究で扱う避難に関わる時間を以下のように定義する。
*1 神戸大学大学院工学研究科 博士後期課程 $\cdot$ 修士 (工学)

*2 神戸大学都市安全研究センター 教授・学博

*3 消防庁消防研究センター 主任研究官・博士 (工学)

*4 神戸大学大学院工学研究科 研究員 ·博士 (工学)

*5 神戸大学大学院工学研究科 元大学院生. 修士 (工学)
Grad. Student, Graduate School of Engineering, Kobe Univ., M.Eng. Prof., Research Center for Urban Safety and Security, Kobe Univ., Ph.D. Senior Researcher, National Research Institute of Fire and Disaster, Ph.D Researcher, Graduate School of Engineering, Kobe Univ., Dr.Eng. Former Grad. Stud., Graduate School of Engineering, Kobe Univ., M.Eng. 
避難所要時間 $\left(T_{H}\right.$ と寸る)：「避難の決定」から「避難完了(荷物注 2) の準備・搬送を含む)」までの時間であり、避難準備時間 $\left(T_{J}\right.$ とす る) と避難移動時間 $\left(T_{Y}\right.$ とする)の組合せである。

避難準備時間 $T_{J}$ : 「避難の決定」から「避難隻備完了(荷物の準備 を含む)」までの時間である。

避難移動時間 $T_{Y}$ :「移動の開始」から「避難完了(荷物の搬送を含 む)」までの時間であり、搬送車両の乗車時間、搬送時間、降車時間、 回送時間 (必要な場合) と搬送回数 (それぞれは $T_{N 、} 、 T_{S} 、 T O 、 T_{S}, \mathrm{~N}$ とする))から算出する $\left(T_{Y}=\left(T_{N}+T_{S}+T_{O}+T_{S}^{\prime}\right) \times \mathrm{N}-T_{S}^{\prime}\right)$ 。 本来なら、避難準備が完了してからの移動開始が普通であるが、 切迫避難などの場合、避難準備を終えることなく移動を開始せざる を得ない可能性がある。そのため、避難準備時間 $T_{J}$ と避難移動時間 $T_{Y}$ の間に重複時間 $\left(T_{C}\right.$ とする。 $T_{C} \geqq 0$ 分 $)$ が発生すると考えられ、 避難所要時間 $T_{H}$ は避難準備時間 $T_{J}$ と避難移動時間 $T_{Y}$ の和から重 複時間 $T_{C}$ を除いたものである $\left(T_{H}=T_{J}+T_{Y}-T_{C}\right)$ 。

\section{2. 自動車による要配慮者避難に関するヒアリング調査 2.1 ヒアリング調査の概要}

筆者らが、2018 年 9 月から 12 月にかけて、2018 年西日本豪雨 で甚大な浸水被害が発生した倉敷市真備町で自動車による避難を行 った事例へのヒアリングなど詳細な調査 7)によると、2018 年 7 月 6

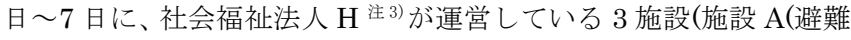
元)、施設 $\mathrm{B}($ 避難元 $)$ 、施設 $\mathrm{C}($ 避難先 $))$ と社会福祉法人 $\mathrm{K}$ が運営して いる 2 施設(施設 $\mathrm{Y}($ (避難元) と施設 $\mathrm{K}($ (避難先))では、それぞれの系列 において自動車による要配慮者避難を連携して行っている。避難時 における施設 A、B と Y の避難経路と交通状況 ${ }^{8)}$ などを Fig.1 に示 す。本章では、関係施設の管理者や職員へのヒアリング調查及び避 難に関わったドライバーへのアンケート調査を基に、各施設の管理 者に不明点をメールで適宜聞き取ることにより、避難元の施設であ る施設 $A 、 B$ と Y での自動車による要配慮者避難について解明寸る。

\subsection{8 年西日本豪雨における真備町の被害}

真備町は岡山県倉敷市の北部に位置し、南北端は丘陵となってお り、その丘陵間の平野部を小田川支流の高馬川と末政川が南流し、 町内を東流する小田川と合流した後、更に地区南東端で高梁川と合 流する。 2018 年 7 月 5 日〜 7 日の 72 時間にわたって、高梁川の上 流は、350〜 450mm の積算降水量 ${ }^{10)}$ を観測しており、この降水によ る高梁川の増水に伴い、小田川との合流点で小田川の水流がせき止 められるバックウォーター現象 ${ }^{10)}$ が発生し、7 日の 0 時頃から明け

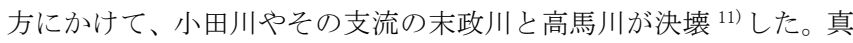
備町は面積の 4 分の 1 にあたる 1,200 ヘクタール ${ }^{12)}$ が浸水し、最大 浸水深が 5.4 メートルに達したと見られ、死者は 51 名 ${ }^{12)}$ となった。

行政の対応として、小田川では 6 日 21 時 50 分に氾濫警戒情報、

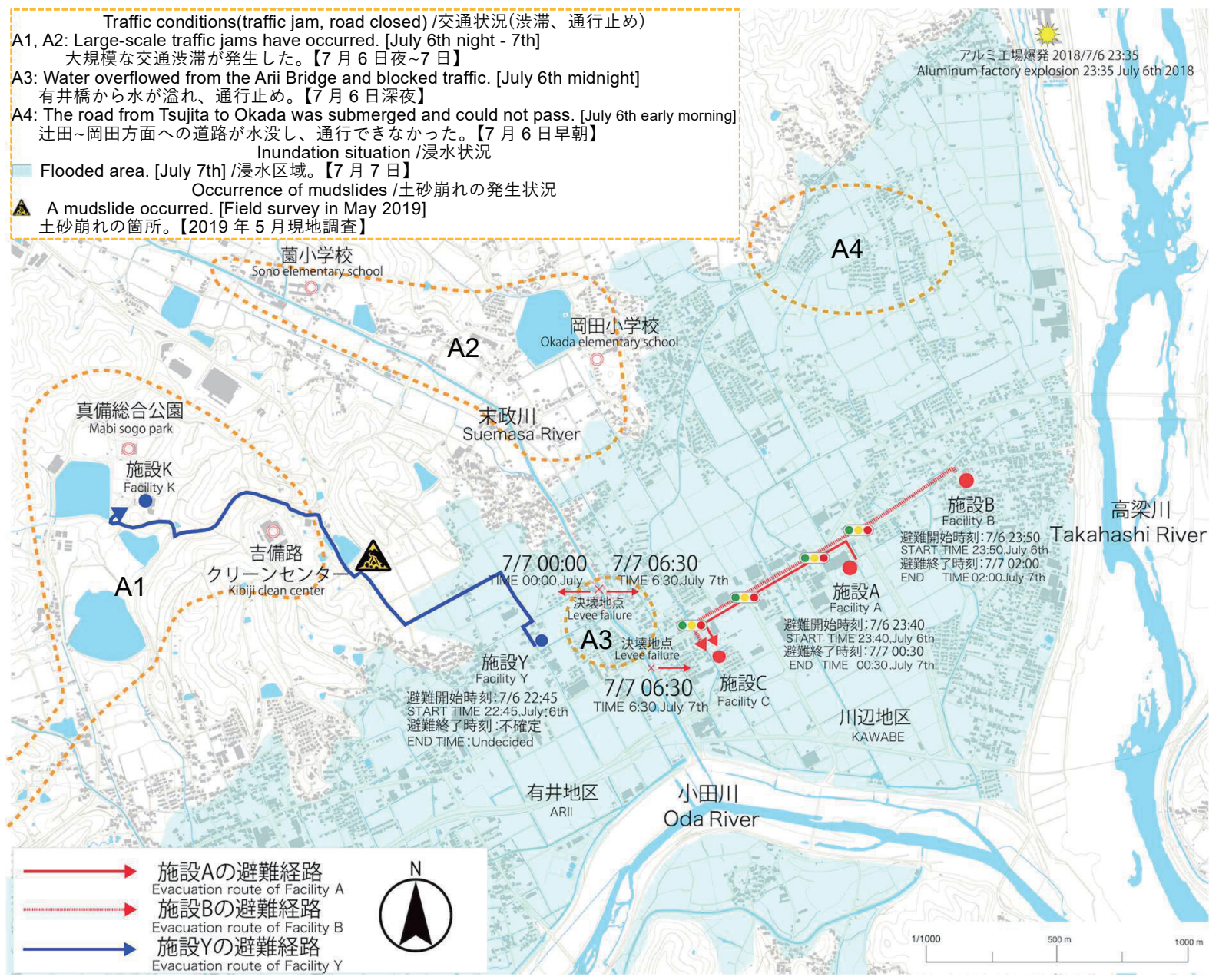

Fig.1 Evacuation routes of surveyed facilities and traffic conditions during the evacuation (Modified by the author based on estimated inundation stage map of Mabi district ${ }^{9)}$ ) 
22 時 20 分と 7 日 0 時 30 分に氾濫危険情報が発令され、その間の 22 時 40 分には倉敷市に大雨特別警報が発令されている ${ }^{13)}$ 。なお、 倉敷市は 6 日 19 時 30 分に市内山沿い、22 時には全域に避難勧告 を発令し、更に、23 時 45 分に小田川南岸、7 日 1 時 30 分には北岸 に避難指示を発令している ${ }^{13)}$ 。それを受けて、6 日 21 時までに真 備町の避難所 3 箇所に 39 人が避難し、7 日 15 時には避難者数は約 3,300 人 ${ }^{14)}$ に達した。特に、 6 日 23 時 35 分のアルミ工場爆発音が 地域の避難に繋がる切迫感の醸成に与えた影響は大きかったと考え られる ${ }^{15)}$ 。

\section{3 ヒアリング調査の結果}

\section{3. 1 洪水発生前の避難確保計画と避難訓練}

施設 $\mathrm{A}$ ・施設 $\mathrm{B}$ は、岡山県倉敷市真備町川辺地区に位置し、小田 川、末政川と高梁川に囲まれている。施設 $\mathrm{A}$ は、1 階建てのグルー プホームで、利用者は高齢者 18 名である。施設 B は、一部 2 階建 て(利用者の居室は 1 階部分)の有料老人ホームで、利用者は高齢者 16 名である。施設 $\mathrm{A}$ ・施設 $\mathrm{B}$ は、居住部分が 1 階にあるため浸水 した場合に被害を受ける可能性があり、1 階までの浸水を想定し、 より堅牢な 3 階建ての施設 $\mathrm{C}$ が避難先として定められていた。2016 年には 3 施設及び関連会社とともに洪水想定の自動車による要配慮 者避難訓練を 2 回実施していた。それを基に、施設 $\mathrm{A}$ では利用者全 員を自動車で搬送するための避難移動時間を 1 時間と概算し、避難 準備・高齢者等避難開始の段階で避難することを事前に決めており、 水防法に規定される避難確保計画の作成はなかったが、実質的な計 画となっていたと考えられる。一方、施設 B ではマニュアルなど明 確な指針はなかった。

施設 Y は、岡山県倉敷市真備町有井地区に位置し、未政川の西側
に隣接している 1 階建ての特別養護老人ホームで、利用者は高齢者 36 名である。施設 $\mathrm{Y}$ として、2 年前に倉敷市から配布された八ザー ドマップで施設が $5 \mathrm{~m}$ 以上の浸水想定区域内にあることを把握して おり、また水害時に水没する可能性も認識していた ${ }^{16)}$ 。そのため、 土砂災害を除き、避難勧告が発令された場合に施設 $\mathrm{Y}$ は高台にある 系列の施設 $\mathrm{K}(3$ 階建て $)$ に避難する取り決めをしていた。水防法に 規定される避難確保計画を作成していたものの、避難訓練の実施は なかった。真備地区の浸水ハザードマップ 17)を Fig.2 に示す。

\section{3.2 自動車による要配慮者避難の時系列}

2018 年西日本豪雨に際して、施設 A は水没したが、死傷者は出 なかった。2018 年 7 月 6 日夕方までに、 $\mathrm{A}$ 施設長は河川の様子を 見に行き、社長注 ${ }^{3)}$ に増水の様子を報告した。20 時頃に、 $\mathrm{A}$ 施設長 は施設 $\mathrm{A}$ 一行き、社長に連絡して避難を決定し、夜勤の職員 2 名で 避難することは難しかったため、応援を要請した。2 21 時 30 分まで に、社長の指示で関連会社注 3$)$ の社員 7 名が駆け付け、避難準備に加 わった。タオルなど持ち出し品の準備、書類とパソコンなどの高い 場所一の移動、利用者にカッパを着せるなどの準備に多くの時間を 要した。避難準備に集中していたため、22 時の避難勧告に気付かな かった。23時 35 分頃に、利用者全員を玄関の近くまで誘導し、避 難移動が開始できるようになった頃に、アルミ工場爆発音を聞いた。 まもなく、社長の指示で $\mathrm{C}$ 施設長と $\mathrm{C}$ 職員 1 名も施設 $\mathrm{A}$ に駆け付 けた。23 時 40 分頃に避難移動を開始し、自動車 4 台で最大 3 回に わたって利用者 18 名を搬送するとともに、もう 1 台の自動車 $(\mathrm{C}$ 施 設長が運転) で車椅子 5 台を搬送し、7 日 0 時 30 分頃に利用者と荷 物の避難が完了した(避難完了)。なお、タオルや寝具等の搬送にも 他の自動車が使用されたため、総数は分からないとの回答であった。

\section{Flood hazard map of Mabi district (The 2017 Year Version)}

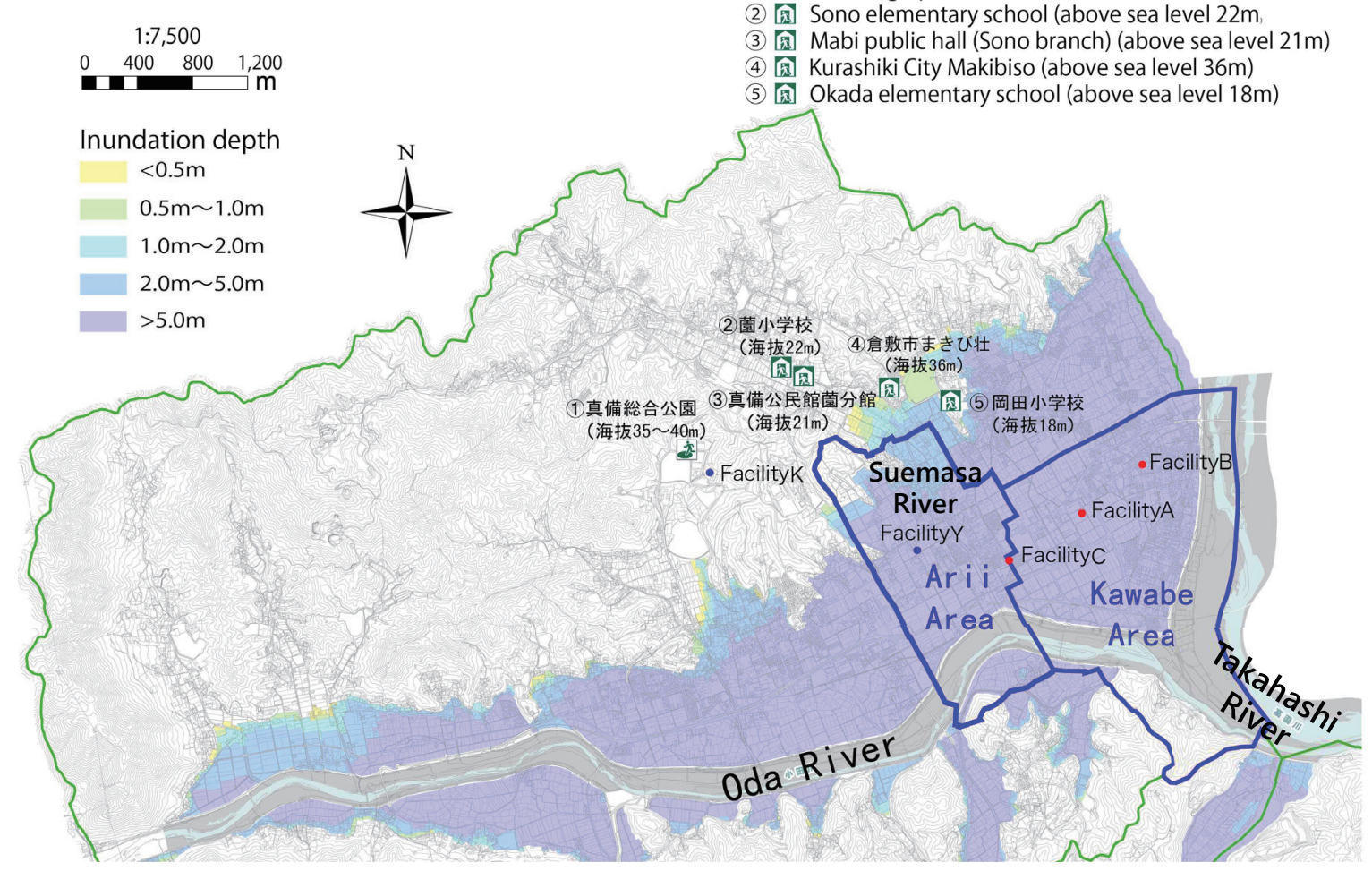

Fig.2 Flood hazard map of Mabi district (The 2017 Year Version) (Modified by the author based on the original figure) 
施設 B は 1 階天井まで浸水したが、死傷者は出なかった。2018 年 7 月 6 日 22 時の避難勧告の発令時点で $\mathrm{B}$ 施設長 (施設に不在) は 避難開始の予定はなかった。2 3 時 35 分頃の工場爆発の直後に、社 長から避難をするように連絡があり、職員を招集した。まもなく、 社長と理事長、施設 $\mathrm{A}$ からの関連会社の社員 4 名も施設 B に駆け 付け、夜勤の職員 1 名を含め、計 7 名で利用者を誘導し始めた。 23 時 50 分頃に、施設 B の職員 1 名が自動車で駆け付け、早く移動で きる利用者 2 名を乗車させ、避難移動を開始した。7 日 0 時に、も う 1 名の施設 $\mathrm{B}$ の職員が駆け付け、避難移動に加わった。0 時 10 分以降に、施設 $\mathrm{A} の$ 避難移動を担当した関連会社の社員 2 名が施設 B の避難移動に移行した。自動車 4 台で最大 2 回にわたって利用者 16 名を搬送し、7 日 1 時頃に利用者の避難が完了した。その後、車 椅子 4 台と寝具などの準備に 40 分程度、搬送に 20 分程度を要し、 2 時頃に荷物の避難が完了した (避難完了)。施設 $\mathrm{A} ・$ 施設 $\mathrm{B}$ での避 難移動の概略図を Fig. 3 に示す。

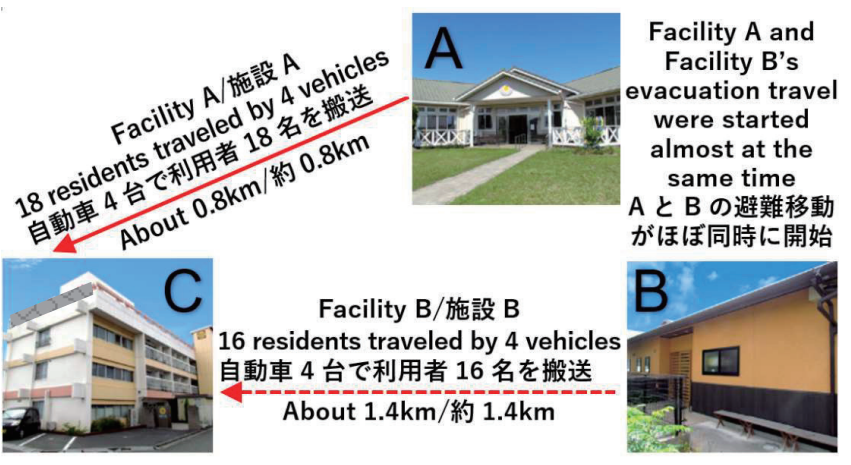

Fig.3 Outline of the evacuation travel from Facility A and Facility B (Facility exterior photos are from the HP of each facility)
施設 Y は屋根まで浸水したが、死傷者は出なかった。2018 年 7 月 6 日昼頃から、Y 施設長はネットで河川の水位を気にしていた。 16 時頃に、避難勧告が発令した場合避難を行うため、緊急招集する 可能性があることと、避難経路を確認しておくことを電話網で職員 に連絡した。施設 $\mathrm{K}$ にも連絡し、利用者の避難スペースについて相 談した。22 時頃に、Y 施設長は携帯のエリアメールで避難勧告を確 認し、22 時 10 分に避難を決定し、職員への緊急招集を連絡網で回 した。22 時 15 分頃に、職員 20 数名が緊急連絡で順次に施設 Y 集まり、利用者を起こしてから、最初の利用者を玄関横のホールに 誘導するまで 30 分程度を要した。 22 時 45 分頃に、施設 $\mathrm{K}$ 一の避 難移動を開始し、搬送車両 7 台(そのうち、22 時 40 分頃に、避難先 の施設 $\mathrm{K}$ から自動車 3 台注 4) と職員 4 名が応援に駆け付けた)で最大 4 回にわたって利用者 36 名を搬送し、0 時頃に利用者の避難が完了 した。施設 Y での避難移動の概略図を Fig.4 に示寸。一方、利用者 避難完了の間近の段階で、施設 $\mathrm{K}$ 一寝具と薬などを搬送しながら、

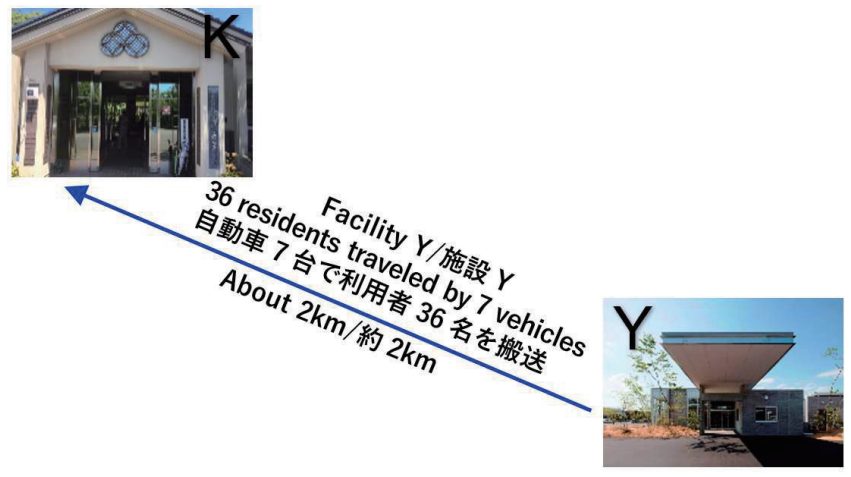

Fig.4 Outline of the evacuation travel from Facility $Y$ (Facility exterior photos are from the HP of each facility)

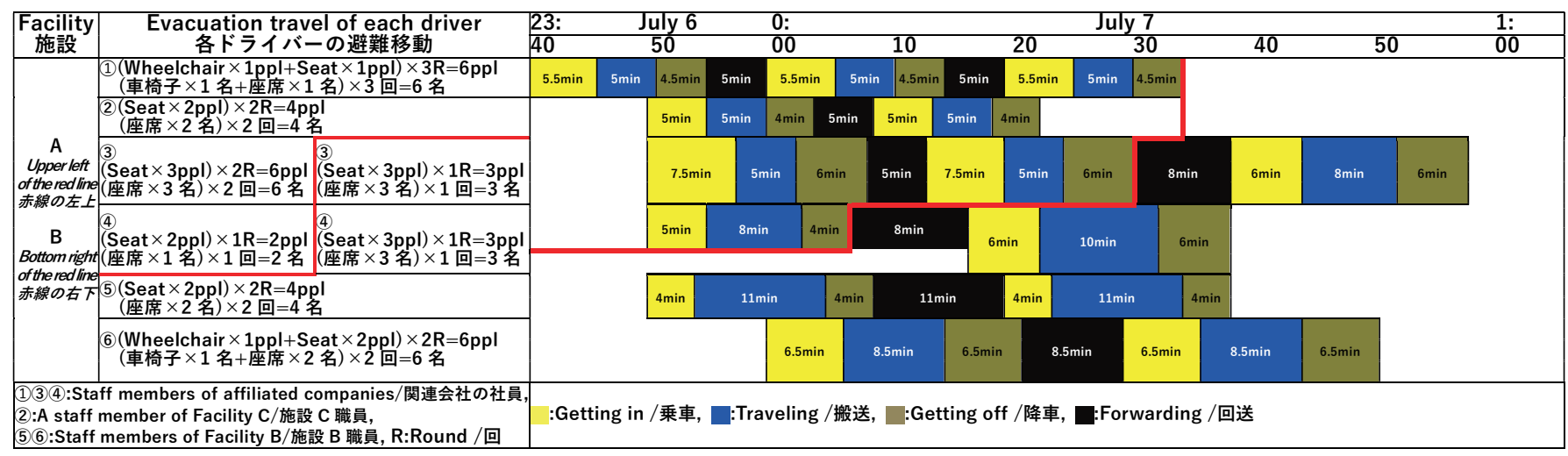

Fig.5 Estimated time distribution of residents' evacuation travel from Facility A and Facility B (July 6 - July 7, 2018)

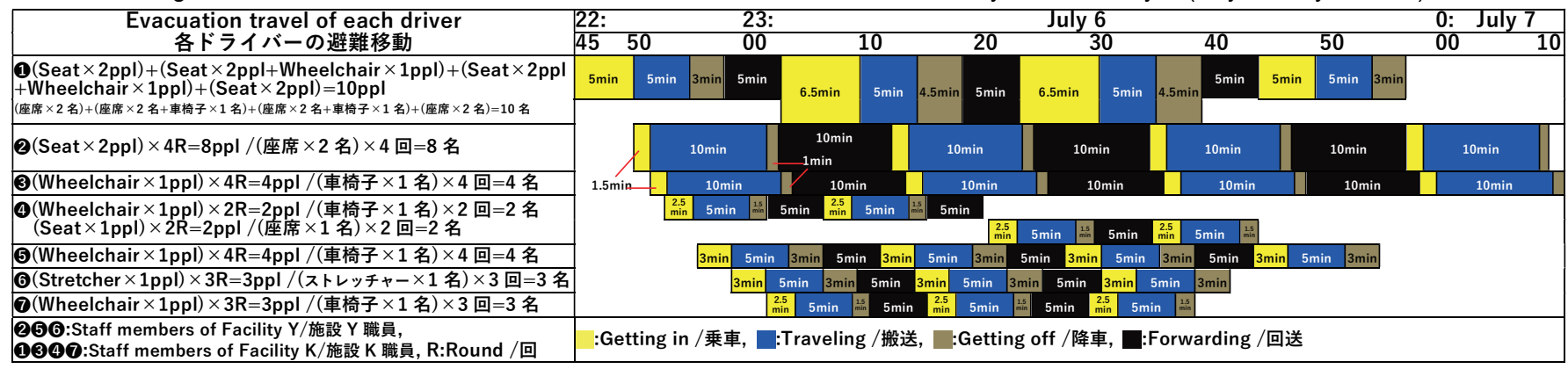

Fig.6 Estimated time distribution of residents' evacuation travel from Facility Y (July 6 - July 7, 2018) 
カーテンや椅子などを施設内の高い場所に移動している間に、末政 川の堤防決壊により施設 $\mathrm{Y}$ が浸水し始め、7 日 0 時 30 分頃に一気 に膝の高さまで浸水していたため、職員 24 名が屋上へ避難せざる を得なかった (避難中止している)。

\section{3.3 利用者の避難移動における時間分布の推定}

各施設で避難移動を担当したドライバーの回答を基に、荷物の搬 送注 5) を除く利用者の避難移動の時間分布を Fig. 5 と Fig. 6 に推定す る(うち、施設 A ではドライバー(1)(2)(3)(4)、施設 B ではドライバー (3)(4)(5)(6)、施設 Y ではドライバーD234560が担当していた。 なお、各施設担当のドライバーは、必ずしも当該施設所属の職員で はない。ドライバーの所属は Fig.5 及び Fig.6 のそれぞれ最下段に 示寸通りである)。ただし、避難移動での全ての搬送時間 $T_{S}$ と回送 時間 $T S$ S はドライバーの回答による時間であったが、搬送車両の乗 車時間 $T_{N}$ と降車時間 $T_{O}$ については、 3 施設でも回答が欠損(回答し たのはドライバー2345だけ)しているため、久損の数值は A 施 設長、避難移動に参加した施設 $\mathrm{B}$ 職員、 $\mathrm{C}$ 施設長と $\mathrm{Y}$ 施設長の証言 を基に推定した。

$\mathrm{C}$ 施設長の証言では、避難移動時の搬送車両の乗降時間は覚えて いないが、施設 $\mathrm{A} \cdot \mathrm{B} \cdot \mathrm{C}$ と関連会社の避難訓練では利用者 1 名を 乗降させるのに 2.5 分以内でできたが、車椅子の方の乗降より座席 の方の乗降のほうが早かったとのことであった。そのため、普段の 乗降時間として、座席 1 名につき 2 分以内、車椅子 1 名につき 2.5 分以内と考えることができる。また、 $\mathrm{A}$ 施設長と $\mathrm{B}$ 職員の証言によ る避難移動時の状況として、施設 $\mathrm{A}$ では「暗くて足場が悪く乗車は 普段より時間がかかった」、施設 B では「乗降はスムーズだった」 とのことであった。そのため、推定の際、施設 B での $T_{N}$ と $T o$ は普 段通りの乗降時間の最大值(座席 1 名につき 2 分と 2 分、車椅子 1 名につき 2.5 分と 2.5 分）を使用、施設 $\mathrm{A}$ での $T_{N}$ と $T_{O}$ の計算は、 $T_{N}$ は施設 $\mathrm{B}$ より 1 名につき 0.5 分を追加した時間、Toは施設 B と 同様の時間(座席 1 名につき 2.5 分と 2 分、車椅子 1 名につき 3 分 と 2.5 分)を使用して計算した。

施設 Y では、ドライバー2045の回答による各自が運転した搬 送車両の乗車時間と降車時間は 1.5 分〜 3 分と 1 分〜 3 分だった。 加えて Y 施設長の証言では、普段では利用者を乗車させるのに、座 席 1 名は 1 分 1.5 分、車椅子 1 名は 1.5 分 2.5 分、ストレッチャ -1 名は 3 分を要し、普段では利用者を降車させるのに、座席 1 名 又は車椅子 1 名は 1 分 1.5 分、ストレッチャー 1 名は 2 分 $~ 3$ 分 を要し、避難移動時の乗降は大体普段通りであったが、普段より早 かった場合もあった。ドライバーの回答と施設長の証言は概社相違 がないため、推定の際、ドライバー2345の $T_{N}$ と $T_{O}$ はドライバ

一2345が回答した時間 (Fig.6 を参照)を使用、ドライバー06 (ひの $T_{N}$ と $T_{O}$ は、 $\mathrm{Y}$ 施設長の証言による普段通りの乗降時間の最大 值(座席 1 名につき 1.5 分と 1.5 分、車椅子 1 名につき 2.5 分と 1.5 分、ストレッチャー 1 名につき 3 分と 3 分)を使用して計算した。

なお、避難移動開始の際、施設 $\mathrm{A}$ の搬送車両は 3 台同時乗車がで きており、施設 $\mathrm{Y}$ の搬送車両は一台ずつ乗車していたこと、また、 複数の利用者の乗降を並行して行っておらず、いずれも 1 名ずつ順 番に行っていたことが各施設の証言で分かった。ドライバー全員の 回答及び以上の証言に基づき推定を行った。推定の結果では、施設 Y の利用者の避難移動完了時刻がヒアリングの結果より 10 分程度
後回しになったが、施設 $\mathrm{A} ・ \mathrm{~B}$ の利用者の避難移動がヒアリング調 査による時系列通りに行われている。

あくまで推定によるものであり、実際の避難移動を完全に再現で きるとは言えない。その理由は、 ( i ) 乗車(降車) 時間は「 $\mathrm{x}$ 分以内」 又は「 $\mathrm{x}$ 分 $\mathrm{y}$ 分」との回答に対し、ほとんどの搬送 (回送) 時間は整 数で回答されており、搬送 (回送) 時間はラウンドナンバーであった 可能性があること、（ii）乗降している車両が前方にいる場合、後続 車両の待ち時間が生じたことによる誤差が発生した可能性があるこ とである。

\section{3．自動車による要配慮者避難の考察}

まず、ヒアリング調查で把握した施設 $\mathrm{A} 、 \mathrm{~B}$ と Y の各種情報を抜 粋したものを Table 1 に示す。

\section{1 調査対象施設における避難所要時間の推定の有無}

施設 $\mathrm{A}$ では水害時のマニュアルがあり、災害時もマニュアルに従 って利用者を施設 $\mathrm{C}$ へ避難させることができた。また 3 施設合同で 水害を想定した自動車による要配慮者避難訓練を行っており、利用 者全員の避難移動には約 1 時間かかることを避難訓練により想定し ていた。施設 B では施設 $\mathrm{A}$ と同じく合同で避難訓練を実施してい たが、マニュアルなど明確な指針はなかった。施設 Y では水防法に 規定される避難確保計画を作成し、ハザードマップを意識しており 防災に関する意識はあったが、避難訓練の実施はなかった。

よって、施設 $\mathrm{A}$ では予め避難訓練により避難移動に時間がかかる ことを把握していたことで、災害時も避難勧告より前に避難準備を 開始することができ、またマニュアルにより避難先や避難移動につ

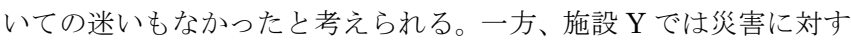
る意識はあったものの、避難訓練で具体的に避難を想定する機会は あまりなかったと考えられる。施設 $\mathrm{A}$ と比較すると避難のタイミン グは避難勧告が発令されてからであり、結果的に職員が逃げ遅れた ことから、高齢者施設での安全性を確保するための避難所要時間を 把握していれば対応や結果が変わっていたかもしれない。

\section{2 避難準備と避難移動の時間関係による避難タイプの分類}

施設 $\mathrm{A}$ は早い段階から天候や避難について検討を行い、行政から の避難情報を待たずに 20 時頃に避難することを決定、自主的避難 の事例として評価することができる。しかし、施設 $\mathrm{A}$ は夜間での支 援要請、持ち出し品の準備、書類とパソコン等の高い場所への移動、 利用者全員の身支度と避難誘導などの準備をしたことで、避難準備 時間 $T_{J}$ は長く、約 3 時間 40 分を要した。避難移動時間 $T_{Y}$ は約 50 分だった。

施設 B は避難勧告の発令から 1 時間 35 分経過して工場爆発が発 生した状況下で、社長の連絡による避難の決定(爆発の直後のため、 23 時 35 分頃と推定される)であったことから、避難体制に問題な いと言えない。支援が迅速に駆け付けたため、22 時 50 分に避難移 動を開始、 1 時 40 分の荷物の搬送開始までに避難移動をしながら避 難準備を行っていた。そのため、避難準備時間 $T_{J}$ は約 2 時間 5 分、 避難移動時間 $T_{Y}$ は約 1 時間 30 分 (うち、利用者の搬送に約 1 時間 10 分、車椅子と寝具の搬送に約 20 分を要した) だった。

施設 $\mathrm{Y}$ は避難勧告が受信されるまでに避難の決定ができず、避難 開始の判断基準に問題ないと言えないが、事前に職員への明確な周 知、避難スペースの確保、避難経路の確認などを行い、スムーズに 
Table 1 Overview of evacuation by vehicles from Facility A, B, and Y during 2018 Japan Floods (July 6 - July 7, 2018)

\begin{tabular}{|c|c|c|c|c|}
\hline \multicolumn{2}{|c|}{$\begin{array}{l}\text { Facility } \\
\text { 施設 } \\
\end{array}$} & 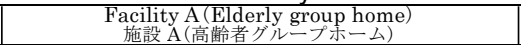 & $\begin{array}{l}\text { Facility B(Private residential home) } \\
\text { 施設 B(有料人老人 }\end{array}$ & 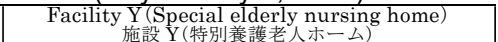 \\
\hline \multicolumn{2}{|c|}{$\begin{array}{l}\text { Location - Adjacent river } \\
\text { 所在地-隣接の河川名 }\end{array}$} & 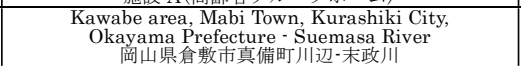 & 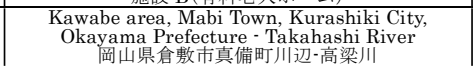 & $\begin{array}{l}\text { Arii area, Mabi Town, Kurashiki City, } \\
\text { Okayama Prefecture-Suemasa River } \\
\text { 成山県倉敷市真備町有井-末本政川 }\end{array}$ \\
\hline \multicolumn{2}{|c|}{$\begin{array}{l}\text { Residents } \\
\text { 利用者数 } \\
\end{array}$} & 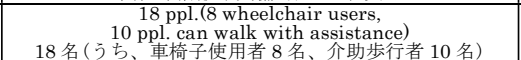 & 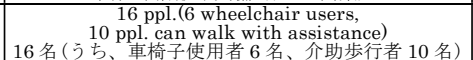 & 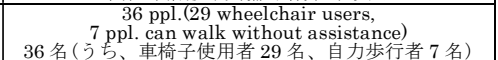 \\
\hline \multicolumn{2}{|c|}{$\begin{array}{c}\text { Shelter, evacuation distance } \\
\text { 避難先、避難距離 }\end{array}$} & $\begin{array}{l}\text { Private residential home } \mathrm{C} \\
\text { 有料贲人条 } \triangle \mathrm{C} 、 0.8 \mathrm{~km} \\
\end{array}$ & $\begin{array}{l}\text { Private residential home C } \\
\text { 有料贲人条 } \triangle \mathrm{C} 、 1.4 \mathrm{~km} \\
\end{array}$ & 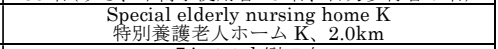 \\
\hline \multicolumn{2}{|c|}{$\begin{array}{l}\text { Evacuation equipment } \\
\text { 搬送機材 }\end{array}$} & 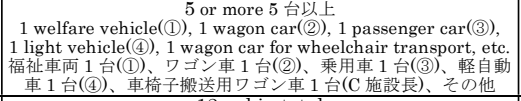 & 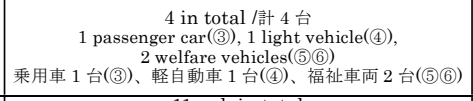 & 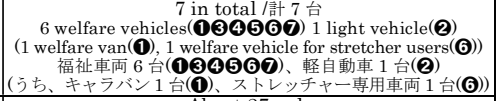 \\
\hline \multicolumn{2}{|c|}{$\begin{array}{l}\text { Supporters } \\
\text { 交援者数 }\end{array}$} & 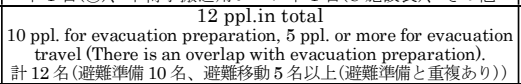 & 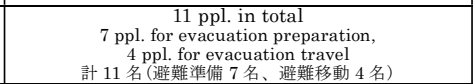 & 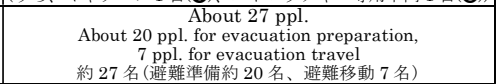 \\
\hline \multicolumn{2}{|c|}{$\begin{array}{c}\text { Preventive measures } \\
\text { 事前対策 }\end{array}$} & 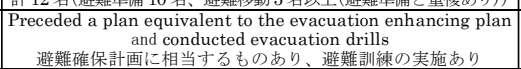 & 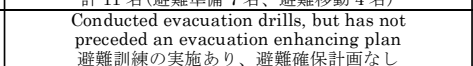 & 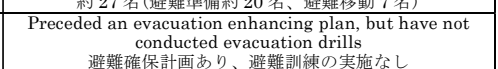 \\
\hline \multirow{3}{*}{\multicolumn{2}{|c|}{ 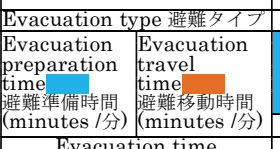 }} & 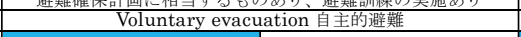 & 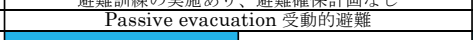 & 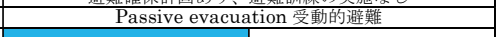 \\
\hline & & \multirow[t]{2}{*}{$220(20: 00 \sim 23: 40)$} & \begin{tabular}{l|l}
$125(23: 35 \sim 1: 40)$ & $70(23: 50 \sim 1: 00)$ \\
\cline { 2 - 2 }
\end{tabular} & \begin{tabular}{|c|c}
$10 \sim 0: 30)$ & Undecided 不磪定 \\
\cline { 2 - 3 } & $(22: 45 \sim)$ \\
\end{tabular} \\
\hline & & & \multicolumn{2}{|l|}{$20(1: 40 \sim 2: 00)$} \\
\hline \multirow{2}{*}{\multicolumn{2}{|c|}{ 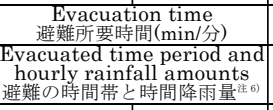 }} & 270 & 145 & Undecided 不碓定 \\
\hline & & $\begin{array}{c}\text { Night of 6th July } 2018 \\
2018 \text { 年 } 7 \text { 月 } 6 \text { 日の夜 }\end{array}$ & $\begin{array}{l}\text { Night of } 6 \text { th July } 2018 \\
2018 \text { 年 7月 } 6 \text { 日の液 }\end{array}$ & $\begin{array}{l}\text { Night of } 6 \text { th July } 2018 \\
2018 \text { 年 } 7 \text { 月 } 6 \text { 日の液 }\end{array}$ \\
\hline $20: 00$ & $5 \mathrm{~mm}$ & 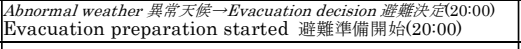 & & \\
\hline $21: 00$ & $8 \mathrm{~mm}$ & & & \\
\hline 22:00 & $23 \mathrm{~mm}$ & Evacuation advisory 避難鹳告(22:00) & Evacuation advisory 避難衔告(22:00) & 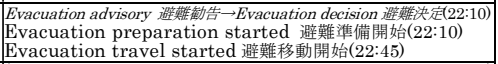 \\
\hline $23: 00$ & $14 \mathrm{~mm}$ & 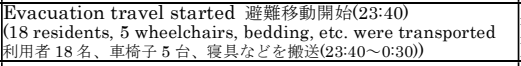 & 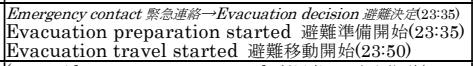 & 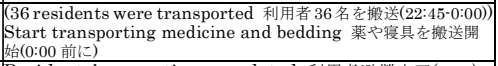 \\
\hline $0: 00$ & $11 \mathrm{~mm}$ & Evacuation completed 避難完了(0:30) & 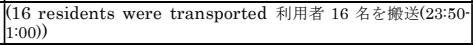 & 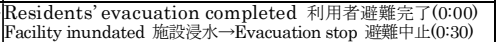 \\
\hline 1:00 & $8.5 \mathrm{~mm}$ & & 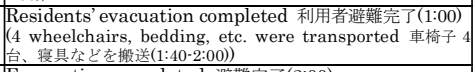 & \\
\hline \multirow{2}{*}{\multicolumn{2}{|c|}{ 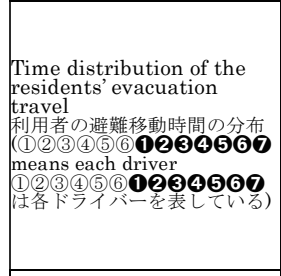 }} & & & \\
\hline & & 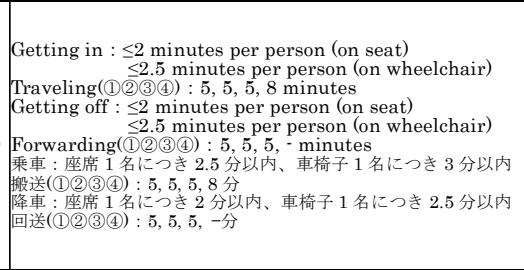 & 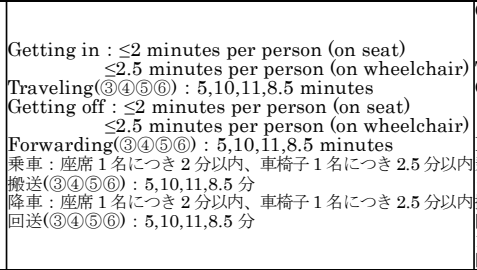 & 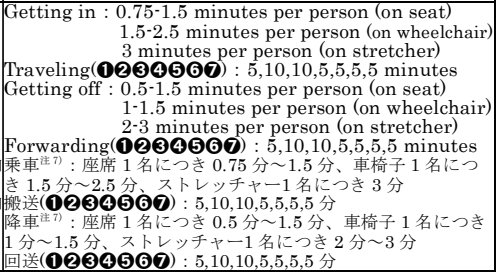 \\
\hline \multicolumn{2}{|c|}{ 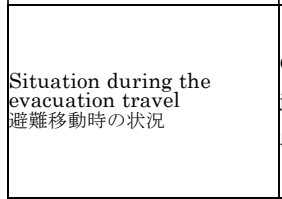 } & 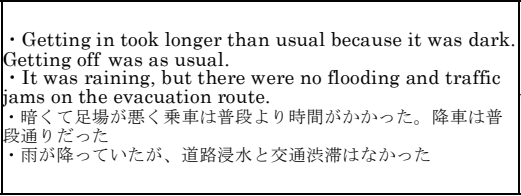 & 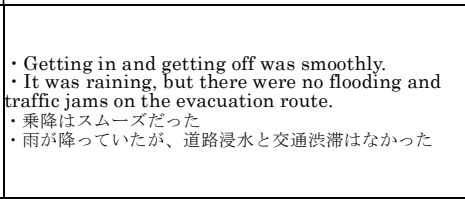 & 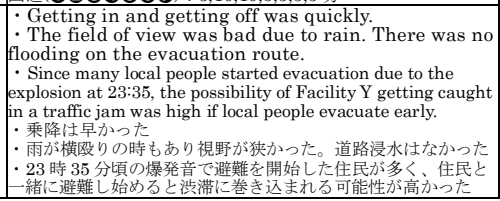 \\
\hline
\end{tabular}

避難準備と利用者の避難移動ができた。2 2 時 10 分に避難すること を決定、22 時 45 分に避難移動を開始、0 時 30 分に職員が施設 Y の 屋上へ避難するまでに避難移動をしながら避難準備を行っていた。 そのため、避難淮備時間 $T J$ は約 2 時間 20 分、利用者の避難移動時 間 $T_{Y}^{\prime}$ は約 1 時間 15 分だったが、薬や寝具など荷物の搬送を完了さ せることができなかったため、避難移動時間 $T_{Y}$ は把握することが できなかった。

以上のことから、この 3 施設の事例を避難タイプに分類すると、 施設 $\mathrm{A}$ は「自主的避難」、施設 $\mathrm{B}$ と施設 $\mathrm{Y}$ は「受動的避難」と考え る。それぞれの特徴として、「自主的避難」である施設 A は避難す るという意思決定が早かったために、避難準備を終えてからの避難 移動であった。それに対し、「受動的避難」である施設 $\mathrm{B}$ と施設 $\mathrm{Y}$ は避難するという意思決定が遅くなったために、避難準備を終える ことなく避難移動を開始せざるを得なかった。

\section{3 避難準備での利用者 1 名ごとの避難準備時間}

避難時に利用者 1 名ごとの避難準備をするのにどのくらい時間を 要したのかを各施設長に尋ねた。Y 施設長の証言では、施設の職員 が最初の利用者を起こしてから、身支度や車椅子への移乗などをし、 部屋から玄関まで誘導するのに約 30 分かかったとのことであった。
一方、 $\mathrm{A}$ 施設長と $\mathrm{B}$ 施設長の証言ではこの時間については把握でき なかった。あくまで 1 施設の証言によるものであるが、夜間かつ豪 雨時で要配慮者の避難準備をするのに長く時間を要することが示唆 された。ただ、利用者の介護度により避難準備で要した時間に差異 があったと考えられ、避難準備での利用者 1 名ごとの避難準備時間 について、今後の調查で明らかにする必要がある。

\section{4 避難移動での利用者の移動状態}

Fig.5 によると、施設 A では利用者 18 名のうち 3 名を車椅子に 乗せて、残りの 15 名を座席に座らせて搬送し、施設 B では利用者 16 名のうち 2 名を車椅子に乗せて、残りの 14 名を座席に座らせて 搬送したこと、Fig.6 によると、施設 Y では利用者 36 名のうち 21 名を車椅子に乗せて、12 名を座席に座らせて、残りの 3 名をストレ ッチャーに横たわらせて搬送したことが分かった。そのため、調査 対象施設では、避難移動での利用者の移動状態として、座席、車椅 子のままとストレッチャーのままという 3 つの移動状態があった。 また、Table 1 による車椅子使用者数が施設 A では 8 名、施設 B では 6 名、施設 Y では 29 名存在したこと、実際にドライバーの回 答から、施設 $\mathrm{A}$ では車椅子 5 台(施設 $\mathrm{A}$ の時系列を参照)、施設 $\mathrm{B}$ では車椅子 4 台(施設 B の時系列を参照)を搬送したことが分かっ 
た。各施設の避難移動での車椅子のまま搬送された利用者数と併せ て見ると、利用者の中には車椅子使用者でも座席での移動が可能な 場合は車椅子と別で搬送された人もいることが考えられる。

\section{5 避難移動での利用者 1 名ごとの乗車時間と降車時間}

避難移動での各搬送車両の乗車時間 $T_{N}$ と降車時間 $T_{O}$ について、 前述したように、3 施設においてもドライバーの回答が久損してお り、久損の数值は $\mathrm{A}$ 施設長、避難移動に参加した施設 $\mathrm{B}$ 職員、 $\mathrm{C}$ 施 設長と $\mathrm{Y}$ 施設長の証言を基に推定したが、これらの数值は利用者の 避難移動における時間分布の推定において辻褄が合っている。

あくまで 3 施設の事例によるものであるが、施設 $\mathrm{A} 、 \mathrm{~B}$ と $\mathrm{Y}$ のデ 一夕を併せて見ると、避難移動での各搬送車両の乗車時間 $T_{N}$ と降 車時間 $T_{O}$ は異なっていたが、利用者 1 名ごとの乗車時間と降車時 間(それぞれは $T_{N 1} 、 T o 1$ とする) として、座席 1 名につき 0.75 分〜 2.5 分と 0.5 分 2.5 分、車椅子 1 名につき 1.5 分 $\sim 3$ 分と 1 分 $\sim 2.5$ 分、ストレッチャー 1 名につき 3 分と 2 分 $~ 3$ 分を要したと概括で きる。ただし、これらの数值は証言による推定のデータが含まれて いるため、今後は事例の蓄積による数值の検証と精度向上が必要で ある。

\section{6 避難移動での搬送車両の走行速度}

各施設の避難距離とドライバーの回答による各搬送車両の搬送 (回送) 時間 $T_{S}$ (Table 1 を参照)を基に、避難移動での搬送車両の走 行速度 $\left(V_{T}\right.$ とする)を算出したものを Table 2 に示す(なお、走行速 度 $V_{T}$ を、避難距離 $\div$ 搬送 (回送) 時間で算出する)。ただし、前述 ( 2 . 3. 3 を参照)のように、搬送 (回送) 時間はラウンドナンバーであっ た可能性があるため、走行速度算出の際、1 分の幅 ( \pm 0.5 分)を与え ることで誤差の影響を配慮する。また、普段では、施設 $\mathrm{C}$ から施設 $\mathrm{A}$ までは 5 分程度、施設 $\mathrm{C}$ から施設 $\mathrm{B}$ までは 8 分程度、施設 $\mathrm{Y}$ か ら施設 $\mathrm{K}$ までは 5 分程度を要することが $\mathrm{C}$ 施設長及び $\mathrm{Y}$ 施設長の 証言で分かった。そのため、施設長の証言による普段での各施設の 走行速度も算出して Table 2 に示寸。

Table 2 Traveling velocity of evacuation vehicles

\begin{tabular}{|c|c|c|c|c|c|c|}
\hline $\begin{array}{c}\text { Evacuation } \\
\text { vehicles } \\
\text { 搬送車両 }\end{array}$ & $\begin{array}{c}\text { Evacuation } \\
\text { distance } \\
\text { 避難距離 } \mathrm{km}\end{array}$ & \multicolumn{2}{|c|}{$\begin{array}{c}\text { Traveling (Forwarding) } \\
\text { time } \\
\text { 搬送 (回送) 時間 } \mathrm{h}\end{array}$} & \multicolumn{3}{|c|}{$\begin{array}{l}\text { Traveling velocity } \\
\text { 走行速度 } \mathrm{km} / \mathrm{h}\end{array}$} \\
\hline (1)(A) & 0.8 & $(5.0 \pm 0.5) / 60$ & \multirow{4}{*}{$\begin{array}{c}\text { Normal } \\
\text { time } \\
\text { 普段 } \\
5.0 / 60 \\
\end{array}$} & $8.7-10.7$ & \multirow{4}{*}{$\begin{array}{c}\text { Mean } \\
\text { 平均 } \\
7.9 \sim 9.6\end{array}$} & \multirow{4}{*}{$\begin{array}{c}\text { Normal } \\
\text { time } \\
\text { 普段 } \\
9.6\end{array}$} \\
\hline (2)(A) & 0.8 & $(5.0 \pm 0.5) / 60$ & & $8.7-10.7$ & & \\
\hline (3)(A) & 0.8 & $(5.0 \pm 0.5) / 60$ & & $8.7-10.7$ & & \\
\hline (4)(A) & 0.8 & $(8.0 \pm 0.5) / 60$ & & $5.6-6.4$ & & \\
\hline (3)(B) & 1.4 & $(5.0 \pm 0.5) / 60$ & \multirow{4}{*}{$\begin{array}{c}\text { Normal } \\
\text { time } \\
\text { 普段 } \\
8.0 / 60\end{array}$} & 15.3-18.7 & \multirow{4}{*}{$\begin{array}{c}\text { Mean } \\
\quad \text { 平均 } \\
10.0 \sim 11.5\end{array}$} & \multirow{4}{*}{$\begin{array}{c}\text { Normal } \\
\text { time } \\
\text { 普段 } \\
10.5\end{array}$} \\
\hline (4)(B) & 1.4 & $(10.0 \pm 0.5) / 60$ & & \begin{tabular}{|l|}
$8.0-8.8$ \\
\end{tabular} & & \\
\hline (5)(B) & 1.4 & $(11.0 \pm 0.5) / 60$ & & $7.3-8.0$ & & \\
\hline (6)(B) & 1.4 & $(8.5 \pm 0.5) / 60$ & & $9.3-10.5$ & & \\
\hline $\boldsymbol{0}(\mathrm{Y})$ & 2.0 & $(5.0 \pm 0.5) / 60$ & \multirow{7}{*}{$\begin{array}{c}\text { Normal } \\
\text { time } \\
\text { 普段 } \\
5.0 / 60\end{array}$} & $21.8-26.7$ & \multirow{7}{*}{$\begin{array}{c}\begin{array}{c}\text { Mean } \\
\text { 平均 } \\
18.8 \sim 22.7\end{array}\end{array}$} & \multirow{7}{*}{$\begin{array}{c}\text { Normal } \\
\text { time } \\
\text { 普段 } \\
24.0\end{array}$} \\
\hline (2) $(\mathrm{Y})$ & 2.0 & $(10.0 \pm 0.5) / 60$ & & \begin{tabular}{|l|}
$11.4-12.6$ \\
\end{tabular} & & \\
\hline (3) $(\mathrm{Y})$ & 2.0 & $(10.0 \pm 0.5) / 60$ & & 11.4-12.6 & & \\
\hline $\mathbf{4}(\mathrm{Y})$ & 2.0 & $(5.0 \pm 0.5) / 60$ & & $21.8-26.7$ & & \\
\hline (5) $(\mathrm{Y})$ & 2.0 & $(5.0 \pm 0.5) / 60$ & & $21.8-26.7$ & & \\
\hline 6(Y) & 2.0 & $(5.0 \pm 0.5) / 60$ & & $21.8-26.7$ & & \\
\hline $\boldsymbol{\theta}(\mathrm{Y})$ & 2.0 & $(5.0 \pm 0.5) / 60$ & & $21.8-26.7$ & & \\
\hline
\end{tabular}

Table 2 では、各施設の避難移動での搬送車両の走行速度の平均 值が普段と近似していることが分かった。その理由として、多くの 搬送車両は普段通りの搬送 (回送) 時間であったことが挙げられる。 一方、普段より搬送 (回送) 時間が長くなった搬送車両もあった。そ の理由は、Table 1 の示すように、避難移動時の降雨量注 6) として、 6 日 22 時をピークに翌日の 7 日 2 時頃まで収まりを見せながら降

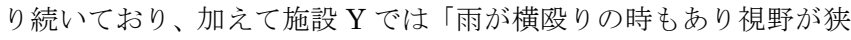
かった」との回答もあったことから、ドライバーにより、降雨によ る影響と避難時の心境も異なっており、普段より時間がかかった可 能性があると考えられる。

また、Table 1 によると、 3 施設での避難移動時の状況として、降 雨量が違っていたにもかかわらず、道路浸水と交通渋滞がなかった。 しかし、避難移動での搬送車両の走行速度 $V_{T}$ は施設によって大き く異なり、施設 $\mathrm{Y}$ の数值は施設 $\mathrm{A}$ ・施設 $\mathrm{B}$ の数值の 2 倍以上である ことが分かった。その理由として、施設 $\mathrm{A} ・$ 施設 $\mathrm{B}$ では避難経路は 信号機のある市街地道路であり、避難移動時に他の車両や信号を常 に注意する必要があり、停車する場合もあったこと、それに対して、 施設 Yでは避難経路は地元住民が利用しない市街地区域外の道路で あり、信号機も設置されておらず、より安定的な走行ができたこと が考えられる。つまり、調查対象の 3 施設において、避難移動での 搬送車両の走行速度 $V_{T}$ は、信号機の有無や走行環境 (市街地、郊外) によって大きく異なったと考えられる。

\section{7 自動車による要配慮者避難における問題}

偶然もあるが、避難移動時に 3 施設とも道路浸水と交通渋滞の影 響はなかった。実際、Fig.1 の示すように、エリア A1 と A2 では、 6 日夜〜 7 日に大規模な交通渋滞が発生したことが分かった。その 原因として、エリア $\mathrm{A} 1$ には、真備地区の主な避難先であった真備 総合公園と吉備路クリーンセンター(指定外避難所) があり、6 日か ら多くの住民が自動車や徒歩で避難してきていた ${ }^{8)}$ 。エリア A2 に は、真備地区の主な避難先であった哣小学校と岡田小学校があり、 この二箇所には、6 日から多くの住民が避難してきており、満員と なっていた ${ }^{8)}$ 。また、エリア A 3 と A4では、橋や道路が水没したた

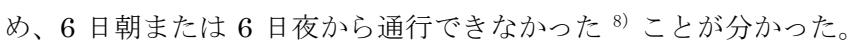

施設 $\mathrm{B}$ の応援に駆け付けた社長の話によると、施設 $\mathrm{B}$ 一向かう 途中に岡田小学校方面で大規模な交通渋滞を目撃した。施設 $\mathrm{A}$ と施 設 $\mathrm{B}$ は、一番近い避難所であった岡田小学校ではなく施設 $\mathrm{C}$ に避 難することによって、交通渋滞を避けられてスムーズに避難移動が できたと考えられる。また、Y 施設長の話によると、施設 $\mathrm{Y}$ は 22 時の避難勧告で避難移動を開始した時には、まだ渋滞は発生してい なかった。その結果、7 日 0 時頃にぎりぎり利用者全員を避難完了 させることができた。2 3 時 35 分頃の爆発音で避難を開始した住民 が多く、住民と一緒に避難し始めると渋滞に巻き込まれる可能性が 高かった。以上のことから、高齢者施設の自動車による要配慮者避 難の実施について、道路交通と浸水情報の収集、早めの判断と避難 移動開始が重要となる。

次に、施設 $\mathrm{Y}$ では避難先までの最短避難経路 (山沿いで池の付近 を通った道路であった。Fig.1 を参照) を普段から利用するとともに 緊急時の避難経路として活用していたことが Y 施設長の証言で分か った。2019 年 5 月、筆者らが現地調査をしたところ、施設 $\mathrm{Y}$ の避 難経路は降雨による土砂崩れで通行止め(Fig.1 を参照) となってい たことから、避難移動の途中に、豪雨により土砂崩れが発生した場 合、施設 $\mathrm{Y}$ の搬送車両は危険に陥る可能性があった。また、施設 $\mathrm{Y}$ の避難経路は幾つかの特定の場所でしか寸れ違いできない道路であ ったことも印象に残った。Y 施設長の証言では、職員同士の暗黙の 理解があったため、避難移動時にスムーズにすれ違いができた。こ のことから、避難移動時のドライバーは施設の職員ではなかった場 
合、スムーズにすれ違いができず、渋滞による時間ロスが発生した 可能性があることがわかった。そのため、高齢者施設が避難経路を 安全に確実に選択できるよう、地域ごとに予め避難経路の指定と整 備を促進する必要がある。

そして、施設 $\mathrm{B}$ と施設 $\mathrm{Y}$ では、利用者の避難移動後に職員は引き

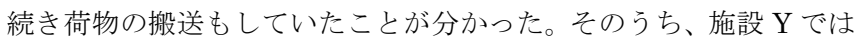
利用者の避難移動完了間近に避難元の施設において荷物の搬送作業 やカーテンや椅子の避難活動を行っていた職員 24 名が施設 Y の屋 上に孤立してしまった。浸水が開始している場合、荷物より身の安 全を守る行動を優先す心゙きだと分かるとともに、非常時に持ち出す 荷物を考えておき、荷物の搬送時間を考慮しておくこと、または、 避難先で荷物を備蓄しておくことなどの対策が職員も守るために必 要であると考えられる。

\section{4. まとめ}

本研究では、2018 年西日本豪雨に際して、3つの高齢者施設間の 自動車による要配慮者避難の時系列を作成し、避難準備と避難移動 の時間関係から避難タイプの分類を行い自動車による要配慮者避難 に関する時間的なデータと有益な知見を得られた。調查対象施設で ある施設 $\mathrm{A} 、 \mathrm{~B}$ と $\mathrm{Y}$ において、他施設への自動車による要配慮者避 難を遂行することができた。そのうち、施設 $\mathrm{A}$ は、水防法に規定さ れる避難確保計画に相当するものを作成しており、避難訓練も実施 していた。施設 $\mathrm{B}$ は、避難訓練の実施のみ、施設 $\mathrm{Y}$ は、避難確保計 画の作成のみを行った。

(1) 自動車による要配慮者避難での所要時間分布と走行速度

(i ) 調査対象施設の避難準備時間 $T_{J}$ と避難移動時間 $T_{Y}$ を見ると、 施設 $\mathrm{A}$ は約 3 時間 40 分と約 50 分、

施設 $\mathrm{B}$ は約 2 時間 5 分と約 1 時間 30 分(重複時間 $T_{C}$ 約 1 時間 10 分)、 施設 $\mathrm{Y}$ は約 2 時間 20 分と不確定(重複時間 $T_{C}$ 約 1 時間 45 分)であっ た。避難タイプとして、施設 $\mathrm{A}$ は「自主的避難」、施設 $\mathrm{B}$ と施設 $\mathrm{Y}$ は「受動的避難」である。

(ii ) 避難準備での利用者 1 名ごとの避難準備時間は、今後の調査 で明らかにする必要がある。

(iii) 避難移動での利用者の移動状態として、座席、車椅子とス卜 レッチャーという 3 つの状態があった。避難移動での利用者 1 名ご との乗車時間 $T_{N 1}$ と降車時間 $T_{O 1}$ として、座席 1 名につき 0.75 分〜 2.5 分と 0.5 分 2.5 分、車椅子 1 名につき 1.5 分 $\sim 3$ 分と 1 分 2.5 分、ストレッチャー 1 名につき 3 分と 2 分 3 分を要したと概括で きる。

(iv) 避難移動時に降雨量が違っていたにもかかわらず、道路浸水 と交通渋滞がなかった状況にあり、搬送車両の走行速度 $V_{T}$ は、信号 機の有無や走行環境(市街地、郊外)によって異なったと考えられる。 避難移動での搬送車両の走行速度 $V_{T}$ (平均值) として、施設 $\mathrm{A}$ は 7.9 $\sim 9.6 \mathrm{~km} / \mathrm{h}$ 、施設 B は $10.0 \sim 11.5 \mathrm{~km} / \mathrm{h}$ 、施設 $\mathrm{Y}$ は $18.8 \sim 22.7 \mathrm{~km} / \mathrm{h}$ であった。

ただし、（iii）と（iv）の数值について、今後は事例の蓄積による数 值の精度向上が必要である。

(2) 自動車による要配慮者避難における知見

( i ) 調查対象施設の自動車による要配慮者避難には他施設など外 部からの協力があった。 (ii ) 受動的避難では、避難準備を終えることなく避難移動を開始 せざるを得なかったことが確認された。

(iii) 避難移動時に車椅子使用者を座席に座らせて車椅子を別で搬 送するという方法が見られた。

(iv) 避難移動時に土砂崩れが発生する恐れがあり、かつ、幾つか の特定の場所でしか搬送車両のすれ違いができない避難経路を選択 した施設があった。

( v ) 利用者の避難移動後に職員は引き続き荷物の搬送もしていた 施設があった。結果的に 1 施設では職員に危険が迫っていた。

高齢者施設をはじめとする要配慮者利用施設が増設しており、豪 雨災害も多発している日本では、実用可能な避難確保計画を作成す るのに、実災害における高齢者施設の避難所要時間に関する様々な 知見が重要となる。今後、これらの知見に基づいて、高齢者施設に おける自動車による要配慮者避難モデルの作成、及び将来の水害を 想定した避難所要時間の予測を目的にさらに研究を進めていきたい。

\section{謝辞}

本研究にあたり多大なご協力を頂きました、法人 $\mathrm{H}$ の社長と 3 施 設の施設長、法人 $\mathrm{K}$ の 2 施設の施設長をはじめ、各施設の職員の皆 様に深く感謝申し上げます。

参考文献

1) Water and Disaster Management Bureau, Ministry of Land, Infrastructure, Transport and Tourism: Guidance for creating an evacuation enhancing plan for facilities used by vulnerable people (excluding medical facilities), 2017.6, www.mlit.go.jp/river/bousai/main/saigai/jouhou/jieisuibou/pdf/hinan kakuho_tebiki_suibou201706.pdf (in Japanese) (accessed 2020.10.7) 国土交通省水管理・国土保全局: 要配慮者利用施設 (医療施設等を除く) に係る避難確保計画作成の手引き,2017.6 (参照 2020.10.7)

2) Cabinet Office, Government of Japan: Disaster Prevention White Paper (Reiwa 1st Year Edition) | Special Feature 1-1 The Heavy Rain Event of July 2018 (West Japan Heavy Rain), 2019, www.bousai.go.jp/kaigirep/hakusho/h31/honbun/0b_1s_01_01.html (in Japanese) (accessed 2021.5.1) 内閣府：令和元年版 防災白書 $\mid$ 特集 第 1 章 第 1節 $1-1$ 平成 30 年 7 月豪雨（西日本豪雨）災害, 2019 (参照 2021.5.1)

3) Ministry of Health, Labour and Welfare: Damage caused by the Heavy Rain Event of July 2018 (49th report), 2018.9 www.mhlw.go.jp/content/10600000/000350123.pdf (in Japanese) (accessed 2019.12.8)

厚生労働省:平成 30 年 7 月豪雨による被害状況等について（第 49 報）, 2018.9 (参照 2019.12.8)

4) OHTsu N., HOKUGO A., PINHEIRO A. and LEE J.: Transport Velocity of Vulnerable People for Tsunami Evacuation. Journal of Architecture and Planning (Transactions of AIJ). Vol.81, No.724, pp.1239-1249, 2016.6 (in Japanese)

大津暢人，北後明彦，ピニェイロ アベウタイチコンノ，李知香：災害 時要援護者の市街地津波避難の搬送速度に関する実験，日本建築学会 計画系論文集, Vol.81,No.724,pp.1239-1249,2016.6.

5) KUME S., HOKUGO A. and LEE J.: Experimental study on transport of vulnerable people from their room to transit car considering zone evacuation from elderly facilities to evacuation centers, Report of Research Center for Urban Safety and Security, Kobe University, No.20,50-58,2016 (in Japanese) 久米智士，北後明彦，李知香:高齢者施設からの広域避難を想定した避 難車両一の要援護者搬送実験,神戸大学都市安全研究センター研究報告, No.20, pp50-58, 2016

6) KANAI J., YUASA Y., NAKANO S. and WATANABE K.: Necessity of 
A Time Line of Flood Disaster in Social Welfare Facility, J. JSCE F6 (safety issue), Vol.71, No.2, pp. I_47-I_54, 2015 (in Japanese) 金井純子, 湯浅恭志, 中野晋, 渡辺一也: 要配慮者移設の初動対応 · 事業継続におけるタイムラインの必要性, 要配慮者移設の初動対応・事 業継続におけるタイムラインの必要性, 土木学会論文集 F6 (安全問題), Vol.71, No.2, pp. I_47-I_54, 2015

7) LIAO J. and HOKUGO A.: Case studies on evacuation using vehicles and vertical evacuation at facilities used by people who need assistance at the time of disaster, Summaries of Technical Papers of Annual Meeting, Architectural Institute of Japan, Fire Safety, pp. 381-382, 2019.7 (in Japanese)

廖解放, 北後明彦: 西日本豪雨時の災害時要配慮者利用施設における自 動車避難移動と垂直避難に関する調査, 日本建築学会大会学術講演梗 概集，防火, pp. 381-382, 2019.7

8) Japan Society of Civil Engineers: Kurashiki City's response to the Heavy Rain Event of July 2018, 2019.9, committees.jsce.or.jp/acecc02/system/files/05_配付資料_倉敷市.pdf (in Japanese) (accessed 2021.4.14)

土木学会: 平成 30 年 7 月豪雨に際しての倉敷市の対応, 2019.9 (参照 2021.4.14)

9) Geographical Information Authority of Japan: Information on the Heavy Rain Event of July 2018 - [Part 7, Estimated inundation stage map], 2018.7, www.gsi.go.jp/BOUSAI/H30.taihuu7gou.html (in Japanese) (accessed 2020.10.20)

国土地理院:平成 30 年 7 月豪雨に関する情報-【7,浸水推定段彩図】, 2018.7 (参照 2020.10.20)

10) YAMAMOTO H., et al.: Change of the Land Use and Characteristics of Flood Disaster by Heavy Rainfall in Mabi Town of Kurashiki City in July 2018, J. JSNDS, Vol.38, No.2, pp.147-168, 2019 (in Japanese) 山本晴彦, ほか 4 名: 2018 年 7 月豪雨により倉敷市真備町で発生した洪 水災害の特徽と土地利用の変遷, 自然災害科学, Vol.38, No.2, pp.147168,2019

11) SANYO News: A timeline of levees broke: 24 hours of Mabi-Cho, 2018.7, www.sanyonews.jp/okayama_gou_timeline (in Japanese) (accessed 2019.6.9)

山陽新聞: 真備町あの日の 24 時間 タイムラインで見る決壊の様子, 2018.7 (参照 2019.6.9)

12) "The Heavy Rain Event of July 2018" Disaster Verification Committee of Okayama Prefecture: Disaster Verification Report on the Heavy Rain Event of July 2018, 2019.3, www.pref.okayama.jp/uploaded/life/601705_5031910_misc.pdf (in Japanese) (accessed 2021.4.13)

岡山県「平成 30 年 7 月豪雨」災害検証委員会: 平成 30 年 7 月豪雨災害 検証報告書, 2019.3 (参照 2021.4.13)

13) Disaster Prevention and Crisis Management Office of Kurashiki City: Disaster Verification Report on July 2018 Heavy Rain, 2019.4, www.city.kurashiki.okayama.jp/secure/134249/r10607kennsyousasik ae.pdf (in Japanese) (accessed 2021.2.7) 倉敷市防災危機管理室：平成 30 年 7 月豪雨災害検証報告書, 2019.4 (参照 2021.2.7)

14) KOMAZAWA University: 2018 Japan Floods - [Evacuation advisories / Evacuation orders at midnight], 2018.7, www.komazawa-u.ac.jp/ fumio/disaster/2018jul-w-japan/rain2018jul-3.html (in Japanese) (accessed 2021.4.14) 駒澤大学：西日本広域豪雨 -【深夜の避難勧告・避難指示】, 2018.7 (参 照 2021.4.14)

15) OKUMURA Y.: Consideration of people's evacuation start during the Heavy Rain Event of July 2018, 18th Symposium on Urban Floods, 2019.11,

www.jsce.or.jp/branch/seibu/symposium/pdf/article_18_02.pdf （in Japanese) (accessed 2021.5.1)
奥村与志弘：平成 30 年 7 月豪雨時の避難開始に関する一考察〜岡山県 の事例〜, 第 18 回都市水害に関するシンポジウム, 2019.11 (参照 2021.5.1)

16) Tokyo Council of Social Welfare: Protect the lives of facility residents by evacuating early based on the inundation assumption area figure, 2019.1, fukushi-portal.tokyo/archives/95/2/ (in Japanese) (accessed 2020.11.15)

東京都社会福祉協議会:ハザードマップの浸水想定に基づいた早めの避 難で利用者の命を守る,2019.1 (参照 2020.11.15)

17) KOMAZAWA University: 2018 Japan Floods - [Flood in Mabi Town, Kurashiki, City] - Hazard Map of the Mabi District, Kurashiki City, 2018.7, www.komazawa-u.ac.jp/ fumio/disaster/2018jul-wjapan/hazardmap-mabi.pdf (in Japanese) (accessed 2021.4.14) 駒澤大学: 西日本広域豪雨-【倉敷市真備町水害】一倉敷市真備地区ハザ ードマップ, 2018.7 (参照 2021.4.14)

注

注1）災害対策基本法では、「高齢者、障害者、乳幼児その他の特に配慮を必 要とする者」を要配慮者としており、なお、「要配慮者のなかでも特に 支援を必要とする者」を避難行動要支援者としている。本研究で扱う高 齢者施設の利用者には避難行動要支援者ではない方が含まれているた め、要配慮者という表現を使用した。

注2）荷物には、車椅子、タオル、寝具、服用薬などが含まれる。

注3）社会福祉法人でありながら、不動産株式会社でもあり、建設会社、建材 会社を経営している。本稿にある「関連会社」は不動産株式会社であり、 「社長」は社会福祉法人と不動産株式会社の社長である。

注4）施設 K からの応援車両 3 台のうち、写真に示すキャラバン(ドライバー (1)が運転)が含まれている。(2018 年 7 月 23 日、施設 $\mathrm{K}$ で筆者が撮影 $)$

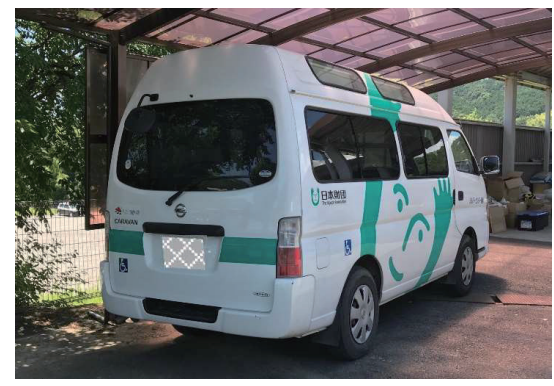

Photo1 A support welfare van from Facility K

注5）Fig.5 と Fig.6 では荷物の搬送が除外されているため、Fig.5 と Fig.6 に ある終了時刻は必ずしも当該施設の避難終了時刻ではない。施設 $\mathrm{A} \cdot \mathrm{B} \cdot$ $\mathrm{Y}$ での荷物の搬送に関する概要 (時間、担当ドライバーと荷物の内容)を Table 3 に示す。

Table 3 Overview of the luggage transportation

\begin{tabular}{|l|l|l|}
\hline \multicolumn{1}{|c|}{ Facility A } & \multicolumn{1}{|c|}{ Facility B } & \multicolumn{1}{|c|}{ Facility Y } \\
\hline Time (23:40 - 0:20) & Time (1:40 - 2:00) & Time (- 0:30) \\
Driver (Facility C Manager) & Driver (3) & Driver $(\mathbf{0})$ \\
Luggage (5 wheelchairs) & Luggage (Quilts and towels) & Luggage (Mattress) \\
\hline \multirow{3}{*}{ Other (Unknown) } & Time (1:40 - 2:00) & Time (- 0:30) \\
& Driver (4) & Driver (3) \\
& Luggage (Quilts) & Luggage (Mattress) \\
\hline & Time (1:40 - 2:00) & Time (- 0:30) \\
& Driver (4) \\
& Luggage (4 wheelchairs) & Luggage (Medicine and Mattress) \\
\hline
\end{tabular}

注6）アメダス矢掛(66391)の 2018 年 7 月 6 日〜 7 日の観測值により抜粋。

注7）施設 $\mathrm{A} ・ \mathrm{~B} ・ \mathrm{Y}$ での乗車時間と降車時間は聞き取り又はドライバーへの アンケートに基づく時間であるが、施設 $\mathrm{A} ・ \mathrm{~B}$ での乗車時間と降車時間

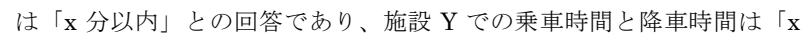
分〜 $\mathrm{y}$ 分」との回答であったため、回答のとおり本研究では使用した。 


\title{
EMPIRICAL ANALYSIS OF VEHICLE EVACUATION OF VULNERABLE PEOPLE BETWEEN ELDERLY FACILITIES DURING HEAVY RAINFALL
}

\author{
Jiefang LIAO ${ }^{* 1}$, Akihiko HOKUGO ${ }^{* 2}$, Nobuhito OHTSU ${ }^{* 3}$, \\ Kazuyoshi OHNISHI ${ }^{* 4}$ and Taishu OMURA *5 \\ ${ }^{* 1}$ Grad. Student, Graduate School of Engineering, Kobe Univ., M.Eng. \\ * 2 Prof., Research Center for Urban Safety and Security, Kobe Univ., Ph.D. \\ * 3 Senior Researcher, National Research Institute of Fire and Disaster, Ph.D. \\ ${ }^{*}{ }^{4}$ Researcher, Graduate School of Engineering, Kobe Univ., Dr.Eng. \\ ${ }^{*}$ Former Grad. Stud., Graduate School of Engineering, Kobe Univ., M.Eng.
}

This study created an evacuation timeline from three elderly facilities (Facility A, B, and Y) using vehicles in Mabi, Okayama during the 2018 Japan Floods. The authors classified evacuation types based on the time relationship between evacuation preparation and evacuation travel, and gained temporal data as well as distinctive findings on the vehicle evacuation of vulnerable people.

(1) Analysis of Evacuation Time Distribution and Traveling Velocity

(i ) First, we obtained the evacuation preparation time $\left(T_{J}\right)$ and the evacuation travel time $\left(T_{Y}\right)$ as follows. In Facility A, each $T_{J}$ and $T_{Y}$ was about 3 hours 40 minutes and 50 minutes; in Facility B, each $T_{J}$ and $T_{Y}$ was about 2 hours 5 minutes and 1 hour 30 minutes (overlapping time is about 1 hour 10 minutes); and in Facility $\mathrm{Y}$, each $T_{J}$ and $T_{Y}$ was about 2 hours 20 minutes and undecided (overlapping time is about 1 hour 45 minutes). Second, we classified the types of evacuation. Facility A was analyzed as "Voluntary evacuation", and both facility B and facility Y were presented as "Passive evacuation".

(ii) Evacuation preparation time per resident needs to be clarified in future research.

(iii) There were three ways of transportation during the evacuation travel; "sitting in the car seat", "sitting in the wheelchair", or "lying on the stretcher". We analyzed the time spent per person for getting in $\left(T_{N 1}\right)$ and getting off $\left(T_{O 1}\right)$ of each way. First, residents who sat in the car seat spent 0.75-2.5 minutes $\left(T_{N 1}\right)$ and 0.5-2.5 $\left(T_{O 1}\right)$. Second, residents who sat in the wheelchair spent 1.5-3 minutes $\left(T_{N 1}\right)$ and 1-2.5 minutes $\left(T_{O 1}\right)$. Lastly, residents who laid on the stretcher spent 3 minutes $\left(T_{N I}\right)$ and 2-3 minutes $\left(T_{O 1}\right)$.

(iv) The traveling velocity $\left(V_{T}\right)$ varied depending on the existence of traffic lights or not or the driving environment (urban area or suburbs). In Facility A, $V_{T}$ (Mean) was about 7.9-9.6 km/h, in Facility B, $V_{T}$ (Mean) was about 10.0-11.5 $\mathrm{km} / \mathrm{h}$, and in Facility Y, $V_{T}$ (Mean) was about $18.8-22.7 \mathrm{~km} / \mathrm{h}$.

(2) Findings on Vehicle Evacuation of Vulnerable People

( i ) All of the surveyed facilities received support from outside such as other facilities.

(ii) Two surveyed facilities that did "Passive evacuation" were starting the evacuation travel before the completion of the evacuation preparation, because of the imminent situation or too many residents.

(iii) Some wheelchair users of the surveyed facilities were sitting in the car seat during evacuation travel, and their wheelchairs were being transported separately.

(iv) One surveyed facility selected an evacuation route where there was a risk of landslides.

(v) Staff members from two surveyed facilities continued to move luggage even after the evacuation of residents, and one of them encountered danger in the end. 